\title{
Przewodniki Andrzeja Podżorskiego (1886-1971) po Wiśle, czyli o początkach nowoczesnego kreowania marki regionalnej Śląska Cieszyńskiego
}

\author{
Renata Czyż iD \\ AGH Akademia Górniczo-Hutnicza, Wydział Humanistyczny, Kraków
}

\begin{abstract}
Streszczenie: Artykuł stanowi analizę trzech wydań przewodnika turystycznego po Wiśle z lat 30. XX wieku, którego autorem był Andrzej Podżorski (1886-1971) - nauczyciel, działacz społeczny i teozof. Ze względu na jego szerokie zainteresowania stale modyfikowana i udoskonalana publikacja na tle ówczesnych wydawnictw turystycznych obejmujących Beskid Śląski jawi się jako nowy i na wskroś oryginalny pomysł. Oprócz standardowej wiedzy turystycznej, propozycji wycieczek i praktycznych wskazówek dla gości letniska w Wiśle autor w swej pracy zamieszcza bowiem niespotykane w innych wydawnictwach informacje na temat kultury (m.in. ośrodka ezoterycznego), działających organizacji społecznych i pobytów znanych twórców literatury. Dzięki temu przewodnik Andrzeja Podżorskiego należy postawić w rzędzie pierwszych nowoczesnych wydawnictw turystycznych na Śląsku Cieszyńskim, a jego samego nazwać pionierem turystyki kulturowej.
\end{abstract}

Słowa kluczowe: historia turystyki, przewodniki turystyczne, Śląsk Cieszyński, dziedzictwo kulturowe, turystyka kulturowa

\section{ANDRZEJ PODŻORSKI'S (1886-1971) GUIDES ON THE TOWN OF WISŁA I.E. THE BEGINNINGS OF THE MODERN CREATION OF THE REGIONAL BRAND OF CIESZYN SILESIA}

\begin{abstract}
The article is an analysis of three editions of the Vistula tourist guide from the 1930s, the author of which was Andrzej Podżorski (1886-1971) - a teacher, social activist and theosophist. Due to his wide interests, the constantly modified and imroved publication, compared to the then tourist publications covering the Silesian Beskids, appears as a new and thoroughly original idea. In addition to the standard tourist knowledge, suggestions for trips and practical tips for quests of the resort in Wisła, the author in his work provides information about culture (including an esoteric center for example), active social organizations and visits of famous writers, unheard of in other publications. Thanks to this, Andrzej Podżorski's guide should be placed in the row of the first modern tourist publications in Cieszyn Silesia, and the author should be called a pioneer of cultural tourism.
\end{abstract}

Keywords: history of tourism, tourist guides, Cieszyn Silesia, cultural heritage, cultural tourism https://doi.org/10.7494/978-83-66727-48-9_2 
W drugiej połowie XIX wieku, w dobie intensywnej urbanizacji i industrializacji ziem polskich, a także Śląska, powszechna stała się wśród mieszkańców miast potrzeba wypoczynku na łonie natury, często połączona z ratowaniem zdrowia. W niewielkiej odległości od ośrodków przemysłowych na Śląsku Cieszyńskim zaczęły powstawać najpierw uzdrowiska, m.in. Jaworze, Mikuszowice Śląskie, Bystra Śląska czy Ustroń, a następnie letniska. Wśród nich jednym z najpopularniejszych stała się Wisła, która przyciągała gości nie tylko nieskażoną przyrodą, ale także źródłami rzeki Wisły, urastającymi do symbolu Polski. Wraz z odkrywaniem wsi przez letników pilna stawała się także potrzeba informacji zarówno ze strony gości, jak i właścicieli pierwszych pensjonatów. Promocją miejscowości i regionu na łamach prasy zajmowali się Bogumił Hoff, jego syn Bogdan Hoff i czasowo osiadły w Wiśle Julian Ochorowicz oraz przybywający do nich goście. Wisła przed I wojną światową pojawiała się na kartach różnych wydawnictw promocyjnych i przewodników, ale brakowało kompleksowego opracowania.

Promocją Wisły na szerszą skalę zajął się Andrzej Podżorski (1886-1971), miejscowy nauczyciel i działacz społeczny, który podjął trud przygotowania do druku przewodnika po Wiśle. Pochodził z wielodzietnej rodziny, a wątłe zdrowie dyskwalifikowało go jako dziedzica rodzinnego gospodarstwa. Ukończył seminarium nauczycielskie w Cieszynie i rozpoczął pracę jako nauczyciel w rodzinnej miejscowości. Jednocześnie zaangażował się w działalność społeczną i podejmował różne zadania jako członek m.in. Polskiego Towarzystwa Pedagogicznego, Macierzy Szkolnej Księstwa Cieszyńskiego i Stowarzyszenia Miłośników Wisły, a w latach międzywojennych Polskiego Towarzystwa Teozoficznego, Związku Górali Śląskich, Związku Narciarskiego i innych. Interesował się wieloma dziedzinami wiedzy i kultury, m.in. teozofią, malarstwem czy ziołolecznictwem. Dokumentował w rysunkach kulturę ludową regionu, zbierał sprzęty gospodarcze i wytwory sztuki ludowej oraz uczestniczył w etnograficznych badaniach naukowych Mieczysława Gładysza, doprowadzając w końcu w 1964 roku do założenia Muzeum Beskidzkiego w Wiśle (Pustówka 1994).

Jedną z najmniej znanych, a najwcześniejszych pasji Andrzeja Podżorskiego była turystyka, której poświęcał wiele czasu nie tylko w latach edukacji w Cieszynie, ale także w wieku dojrzałym. Od zawsze nosił w sobie ciekawość świata i tęsknotę za górską wędrówką oraz odległymi podróżami. Nie miał zbyt wielu możliwości w tym zakresie, ale te marzenia, które znalazły się w jego zasięgu, zrealizował. Najważniejszym jednak zadaniem, jakie sam przed sobą postawił, było przybliżenie turystom Wisły i Beskidu Śląskiego. Za jego życia rodzinna miejscowość z nieznanej wsi zmieniła się w letnisko, w latach międzywojennych w popularny kurort, a po II wojnie światowej w ośrodek wypoczynkowy i bazę turystyki masowej. Andrzej Podżorski dostrzegał potrzeby przybywających gości i wychodził im naprzeciw.

Jak sam pisał, na początku XX wieku w Wiśle, stanowiącej doskonały punkt wypadowy w góry Beskidu Śląskiego, ruch turystyczny praktycznie nie istniał. Nie było 
szlaków ani przetartych ścieżek, którymi wędrowcy mogliby podążać na wybrane szczyty. Jedyne zaplecze turystyczne stanowiły jednopiętrowy budynek kupca Maurycego Rotha z 16 pokojami i dwiema kuchniami (jedną koszerną), który jednak spłonął, oraz Gasthaus zum Rackelhahn znajdujący się obok arcyksiążęcej wylęgarni ryb i budynków nadleśnictwa. Oba punkty obsługiwały niemieckich turystów i Polacy nie mogli liczyć w nich na gościnę (Podżorski 1961). Oczywiście polski ruch letniskowy był już w pełnym rozkwicie, wyprawy do źródeł Wisły, symbolicznego początku nieistniejącej na mapach Polski, odbywały się przez cały wiek XIX, ale dopiero od początku XX stały się bardziej popularne (Czyż 2014). Początkowo turystów letników prowadzili lub wieźli na Przysłop wozami miejscowi przewodnicy górale, a polscy goście zwiedzali źródła Wisły, szczyt Baraniej Góry i wodospady, odpoczywając w szkole w dolinie Czarnego lub w leśniczówce na Przysłopie (Wysłouchowa 1900). Masywu Baraniej Góry bronił przed turystami arcyksiążęcy zarząd lasów, który chronił ostoję zwierzyny łownej, przede wszystkim głuszca, dla polującej pary arcyksiążęcej i jej gości. Dlatego ten rejon długo pozostawał niedostępny dla turystów, których (zwłaszcza polskich) służba leśna po prostu przepędzała (Sosnowski 1926, Galicz 1931: s. 83-84).

Polski ruch turystyczny zaczął się rozwijać w formie zorganizowanej od 1910 roku, kiedy w Cieszynie powołano do życia Polskie Towarzystwo Turystyczne „Beskid”, którego zasługą była budowa w 1913 roku pierwszego polskiego schroniska na Ropiczce (Podżorski 1961, Sikora 1985). Andrzej Podżorski odbywał już wcześniej krótkie wycieczki, m.in. do Jaworzynki do kolegi z ławy szkolnej, poety i późniejszego legionisty, Jana Łyska, z którym się przyjaźnił (Podżorski 1970). Do PTT wstąpił więc od razu w 1910 roku w odpowiedzi na apel działacza oświatowego, a następnie inspektora szkół Karola Buzka, gdyż (jak opowiadał Władysławowi Sośnie), od siedmiu lat regularnie odbywał górskie wycieczki z kolegami Janem Szturcem i późniejszym lekarzem Pawłem Raszką. Przyczynił się również do rozwoju turystki narciarskiej i rowerowej. W 1908 roku wraz z kolegami nauczycielami Jerzym Niemcem i Janem Pilchem sprowadzili ze Szwajcarii pierwsze prawdziwe narty, a później na rowerach przemierzyli cały Śląsk Cieszyński. Zapuszczali się i w dalsze tereny: Beskidy aż po Nowy Sącz, Tatry, a także Gdańsk i Alpy (Sosna 1961). Przed I wojną światową młody nauczyciel miał zamiar wyemigrować do Brazylii i tam uczyć dzieci polskich emigrantów, ale pomysłu tego nie wcielił w życie (Podżorski 1970).

Nawet w latach 20. XX wieku, kiedy zainteresowania Andrzeja Podżorskiego skupiły się na innych dziedzinach wiedzy i życia, nie zaprzestawał on wycieczek w bliższe i dalsze okolice. Dokumentując kulturę ludową i zbierając eksponaty dla muzeów na Śląsku, a później dla przyszłego muzeum wiślańskiego, wędrował od domu do domu i zwiedzał najmniej uczęszczane zakątki Wisły. Wraz z etnografami odwiedził prawie wszystkie górskie miejscowości Beskidu Śląskiego, a nawet wziął udział w wyprawie badawczej Mieczysława Gładysza na Spisz i Orawę (Podżorski 1970). Pasję turystyczną 
przekazywał swym dzieciom, a zapewne także uczniom. Jeden z synów wspominał, że ojciec zabierał go na wycieczki w góry w celach krajoznawczych, ale też dla odwiedzania góralskich domów i prowadzenia rozmów na temat poprawy bytu górali. Ponadto spotykał się z przedstawicielami świata literacko-artystycznego, m.in. Zofią Kossak, którą odwiedził w Górkach Wielkich (Podżorski A. 1994) ${ }^{1}$.

Największą troską Andrzeja Podżorskiego był jednak letnik turysta przybywający do Wisły na wypoczynek i w celach krajoznawczych. Po wybudowaniu linii kolejowej, której stacja w 1929 roku znalazła się niedaleko domu Andrzeja Podżorskiego, ruch turystyczny rozwijał się bardzo intensywnie, by w latach 1937-1939 stać się masowym (Szczypka i Pylypenko-Czepczor 2017). Wisła miała kilka niewielkich folderów, w zasadzie reklamówek, dotyczących miejscowości i poszczególnych willi, ale były one przestarzałe, a nakłady wyczerpane, i powszechnie odczuwano brak szerszej informacji na temat miejscowości. Monografia autorstwa Bogumiła Hoffa była już trudno dostępna, nie uwzględniała ponadto głębokich zmian, jakie zaszły w Wiśle na przestrzeni ponad 40 lat od jej wydania w 1888 roku. Andrzej Podżorski postanowił wypełnić tę lukę i opracować przewodnik po Wiśle.

Trudno wskazać, co było bezpośrednią przyczyną podjęcia tego zadania. Być może zainspirował go któryś z wydanych wcześniej przewodników, którego autor wspomniał o Wiśle, ale nie opisał jej dokładnie. Być może przyczyną była spóźniona informacja o nagrodzie, którą przed I wojną światową ustanowił rząd krajowy w Opawie za sporządzenie szczegółowego opisu Wisły. Andrzej Podżorski wspomina o niej na pierwszych stronach swego przewodnika, oskarżając długoletniego wójta Pawła Raszkę, że schował nadesłane z Opawy pismo i nie upublicznił ważnej informacji. Po latach, patrząc z dystansu, przyznawał jednak, że być może to sprawiło, że Wisła nie stała się niemieckim, ale polskim letniskiem (Podżorski 1930). Inną przyczyną napisania przewodnika mogło być częste udzielanie informacji przez miejscowych nauczycieli, wynajmowanie przez nich pokoi letnikom we własnych domach i zaangażowanie w działania Towarzystwa Miłośników Wisły (Spyra 2007: s. 241-242), do którego należał również Andrzej Podżorski. Sytuacja materialna tej grupy zawodowej nie była najlepsza, a on miał na utrzymaniu dziewięcioosobową rodzinę, dla której zapewnienia bytu m.in. założył sklep z materiałami piśmienniczymi (Pustówka 1994).

Pierwsze wydanie przewodnika Andrzeja Podżorskiego po Wiśle było bardzo skromne i mieściło się na zaledwie 32 stronach, ale ukazało się z dodatkiem mapki.

1 Spośród znanych osób, z którymi spotykał się Andrzej Podżorski (wg jego relacji), wskazać należy także: budowniczych wiślańskiego letniska Juliana Ochorowicza, Henryka Dynowskiego, ks. Juliusza Bursche, Bogdana Hoffa i Jerzego Warchałowskiego; artystów malarzy i grafików: Ludwika Konarzewskiego, Jana Wałacha, Pawła Stellera, Henryka Stabrowskiego; literatów: Bolesława Prusa, Marię Konopnicką i Tadeusza Boya-Żeleńskiego, etnografów i naukowców, których badania czynnie wspierał. 
Nakładem autora, który przedmowę datował na maj 1930 roku, pracę wydrukował Adam Wałach w Ustroniu. Przewodniczek zawierał krótki rys rozwoju Wisły jako letniska od czasów arcyksiążęcych przyjazdów na polowania na głuszce, przez „odkrycie” wsi przez Bogumiła Hoffa, budowę drewnianego letniska przez Juliana Ochorowicza i Henryka Dynowskiego, po przyjazdy literatów i budowę zakładu leczniczego, który zniszczyła powódź. W postawionej przez siebie diagnozie autor wyrażał zadowolenie z rozwoju wsi pod rządami wojewody śląskiego Michała Grażyńskiego, ale wskazywał na liczne braki, m.in. mieszkań i potrzebę odbudowy zakładu hydropatycznego. Ponadto Andrzej Podżorski w swej pracy krótko charakteryzował położenie geograficzne Wisły i łagodne ukształtowanie terenu oraz klimat sprzyjający leczeniu kilku grup chorych, opisywał mentalność i stroje „ludności tubylczej”, o której rozpicie oskarżał Komorę Cieszyńską i byłego wójta. W swej pracy skupił się jednak na informacjach praktycznych przeznaczonych dla przyjezdnych, wymieniając najważniejsze pensjonaty, wille i schroniska turystyczne, sklepy i gospody oraz wskazując na możliwości aprowizacyjne na wiślańskim targu czy bezpośrednio u gospodarzy. Sporo miejsca poświęcił na opis „rozrywek i wygód”, do których zaliczył wycieczki, przedstawiając ich propozycje bez dokładnych wskazówek dotyczących drogi. Polecał wędrówkę na Baranią Górę, do źródeł Wisły i do wodospadów Białej Wisełki, na Stożek i Czantorię, do Jaskini Malinowskiej i do sąsiedniej Istebnej. Mniej wytrwałym rekomendował spacery dolinami Dziechcinki, Łabajowa, Malinki, Czarnej Wisełki, Gościejowa, Jawornika i Gahóry, a także na przełęcz Kubalonkę i okoliczne szczyty. Nie zapomniał wymienić nowych skoczni narciarskich na Baraniej i w Łabajowie oraz dostępnych rozrywek, czyli biblioteki Koła Macierzy Szkolnej, występów teatralnych i folklorystycznych, zabaw ludowych, a także kortów tenisowych. Wśród udogodnień wskazał istnienie poczty i telegrafu, obecność we wsi dwóch lekarzy, doprowadzenie linii kolejowej i asfaltowej drogi, regulację rzeki oraz planowaną budowę basenu i wskrzeszenie przemysłu ludowego. Już wtedy wysunął również postulat stworzenia muzeum w Wiśle (Podżorski 1930).

W przewodniku dominuje podejście praktyczne, najwyraźniej autor miał na celu udzielenie konkretnych wskazówek, a nie pogłębianie wiedzy przybyłych. Świadczą o tym informacje na temat rozwoju ruchu turystycznego od czasów austrowęgierskich przez założenie PTT „Beskid” po uruchomienie schroniska pod Baranią Górą i budowę schroniska na Stożku, informowanie o schroniskach na granicach wsi: niemieckim na Czantorii i polskim na Równicy oraz wskazanie dróg dojazdowych do Wisły z różnych kierunków, także z przepustkami od czechosłowackiej strony. Najciekawszą propozycją turystyczną Andrzeja Podżorskiego jest dwudniowa wycieczka dookoła Wisły z Czantorii przez Stożek, Kubalonkę i dolinę Czarnej Wisełki na Przysłop, a dalej przez Baranią Górę, Malinowską Skałę, Kamienny i Bukową do Wisły (z noclegiem na Przysłopie). Żeby uatrakcyjnić swój przewodnik, autor dodał do niego także rozdział pt. Głosy prasy o Wiśle, w którym przytacza kilka fragmentów artykułów z prasy 
archiwalnej i bieżącej, broszur i innych przewodników turystycznych, a w uwagach końcowych wysuwa szereg postulatów, których spełnienie zapewni (w przekonaniu autora) dalszy rozwój miejscowości. Wśród nich znajdują się już planowane przez urząd wojewódzki budowa basenu, dalsza regulacja rzeki i potoków oraz wprowadzenie planu regulacyjnego. Autor zawarł także w przewodniku uwagi krytyczne wobec zamiarów władz. Uczula, by nie dopuścić do budowy fabryk w Wiśle oraz zachować rozrzuconą zabudowę, zamiast tworzyć zwartą strukturę miejską, postuluje udostępnić turystom Jaskinię Malinowską, odnowić sałasze, czyli gospodarstwa pasterskie w górach, i przemysł domowy ${ }^{2}$, a także wznieść symboliczny pomnik źródeł Wisły (Podżorski 1930).

W środku przewodniczka znalazła się mapka całej Wisły z naniesionymi drogami, rzekami i potokami czy punktami orientacyjnymi, takimi jak kościoły, szkoły i gospody. Wiadomo, że Andrzej Podżorski sporządził ją samodzielnie, nanosząc na nią później także szlaki wyznaczone w latach 20. XX wieku przez PTT, których opis (kolory, gdyż mapka jest czarno-biała) znalazł się pod spodem karty. W kolejnych wydaniach przewodnika udoskonalał zarówno mapę, jak i opisy szlaków, dokonując szkiców terenu i pomiarów odległości. Syn Jan Podżorski wspominał, w jaki sposób ojciec mierzył odległości potrzebne mu do przewodnika: stare, wojskowe mapy austriackie uzupełniał szczegółami z własnych pomiarów, a odległości wyznaczał za pomocą roweru - na jego kole umieszczał znak, prowadząc rower, liczył obroty, które następnie mnożył przez średnicę koła, dzięki czemu mógł podawać precyzyjne czasy przejścia danej trasy (Podżorski J. 1994). Na dodatek Andrzej Podżorski cały (zapewne niewielki) pierwszy nakład lub jego większość rozdał, co potwierdza egzemplarz przewodnika zachowany w Książnicy Cieszyńskiej zawierający dedykację autora dla wspomnianego już Karola Buzka ${ }^{3}$.

Po trzech latach Andrzej Podżorski zaczął przygotowywać drugie wydanie swej pracy, które - datowane na lata 1933-1934 - tym razem drukował Paweł Mitręga w Cieszynie. Zachowane w Muzeum Beskidzkim egzemplarze mają różnego koloru okładki i zostały wydrukowane na odmiennym papierze, stąd wniosek, że dość szybko wykonano dodruk tego samego wydania. Autor we wstępie wskazał bezpośrednie przyczyny podjęcia pracy nad przewodnikiem: pierwszy był bardzo skromny i jego nakład został wyczerpany, Wisła zaś ze względu na swoją rozległość ponownie potrzebowała tego typu wydawnictwa dla turystów. Autor więc poszerzył pracę o wiadomości z przeszłości Wisły i informacje o jej walorach przyrodniczych, sporządził nową mapę i dodał nowe inseraty (reklamy pensjonatów), a do czytelników zwrócił się o przekazywanie swoich uwag. Przewidywał, że potrzebna będzie kolejna edycja i chciał wskazówki odbiorców wykorzystać w dalszej pracy nad przewodnikiem (Podżorski 1933-1934).

2 Chodzi o domową produkcję np. materiałów z lnu lub wełny oraz rozwój rzemiosła, także artystycznego.

3 Egz. Książnica Cieszyńska, sygn. C I 003477. 
Drugie wydanie różni się od pierwszego nie tylko objętością i nową mapą, ale przede wszystkim dodaną obszerną informacją na temat dziejów Wisły. Andrzej Podżorski przyznaje, że z powodu niskiej wiarygodności publikowanych dotąd informacji i niekompletności źródeł, m.in. kronikach szkolnych i kościelnych, korzystał z badań historycznych ks. Andrzeja Wantuły, wikarego, a następnie proboszcza wiślańskiej parafii ewangelickiej, który udostępnił mu swoje rękopiśmienne notatki (Wantuła 1937). Przychyla się do jego tezy o późnym założeniu „wsi na Wisłach” (w II połowie XVI wieku/początku XVII), wspomina o budowie pierwszego, drewnianego kościoła, który nie został zwrócony ewangelikom prześladowanym w czasach kontrreformacji, i niegdyś wspólnym cmentarzu, a także przytacza rozważania uczonego Jana Rozwadowskiego na temat pochodzenia nazwy rzeki Wisły z sanskrytu. Informuje czytelnika o istnieniu dwóch podań wiślańskich (o królowej Boranie i jej córkach Wisełkach oraz o założycielu wsi, Imku Wisełce), ale ma pełną świadomość, że nie są to podania ludowe, lecz „twór fantazji inteligenta”, czyli Bogumiła Hoffa (Podżorski 1933-1934).

Rozszerza Andrzej Podżorski swój opis rozwoju letniska w Wiśle od początku XX wieku, wśród pierwszych budowniczych willi wymieniając także Jerzego Warchałowskiego i ks. Juliusza Bursche oraz przekazując wiadomość o niezrealizowanym planie budowy przez Austrię kanału Dunaj - Odra, w związku z którym Wisła i Brenna miały zostać zalane i stać się zbiornikami zasilającymi tę drogę wodną. Uzupełnia także przekaz o współczesnej Wiśle, która dzięki poparciu władz polskich rozwija się, przyjmując coraz więcej gości i staje się nie tylko letniskiem, ale także zimowiskiem i uzdrowiskiem z nowym basenem kąpielowym. Autor zmienia kolejność niektórych rozdziałów, np. przesuwa głosy prasy na temat Wisły z końca do środka książki i dodaje nowe fragmenty o narciarstwie oraz sportach zimowych oraz bogactwie wiślańskiej przyrody, wymieniając lecznicze zioła, grzyby i zwierzęta, jakie można spotkać na terenie wsi. Informuje też o dawnej gospodarce szałaśniczej i jej upadku. Praktycznie nie ma części, której w drugim wydaniu Andrzej Podżorski by nie uzupełnił, a to za sprawą szybko zachodzących w Wiśle zmian, powstawania nowych schronisk, willi czy pensjonatów, organizacji zawodów sportowych w nowych dyscyplinach oraz stopniowego docierania przez autora do nowych i starszych publikacji na temat miejscowości. Andrzej Podżorski stale poszerzał swoją wiedzę i korzystał z uwag czytelników, zapewne przede wszystkim miejscowych. W drugim wydaniu przewodnika pojawiają się krótkie opisy proponowanych tras turystycznych i atrakcji napotykanych na szlaku, takich jak skały, wodospady, altanka czy Zamek Prezydenta, obecne są krótkie charakterystyki przysiółków i osiedli wiślańskich oraz skorowidz odległości pomiędzy punktami wycieczkowymi wraz ze znakami i czasami przejścia. Ponadto autor podaje wiele informacji praktycznych o możliwościach zakwaterowania i aprowizacji, obowiązku meldunkowym i opłacie klimatycznej, dostępnych bibliotekach i innych rozrywkach. $\mathrm{Na}$ końcu przewodnika zamieszcza szereg reklam poszczególnych sklepów i pensjonatów, 
w których znajdują się m.in. prywatne biblioteki i fortepiany oraz takie nowości jak radio, patefon czy bilard.

Trzecie wydanie przewodnika powstało przy udziale osób trzecich, zapewne z gminy Wisła. Do zmienionego przez autora tekstu dodano obszerny wstęp Od wydawcy zakończony pochwałą sanacyjnych władz wojewódzkich i lokalnych. Jego autor obszernie cytuje Gustawa Morcinka i korzysta z pracy historycznej ks. Andrzeja Wantuły, bazując na tekście o dziejach Wisły z poprzedniego wydania pracy Andrzeja Podżorskiego (Podżorski 1938). Ten został zaznaczony jako autor części turystycznej i ponownie ją zmienił. Niektóre partie swojej pracy usunął, np. część przyrodniczą, a niektóre relokował lub rozbudował, np. opisy przysiółków czy informacje na temat rozwoju ruchu turystycznego. Dodał również nowe charakterystyki wiślańskich dolin, które zostały nazwane osiedlami uzdrowiskowymi, choć Wisła nigdy nie miała statusu uzdrowiska. Wszystkie rozdziały zostały uzupełnione o informacje o nowo powstałych obiektach sportowych i użyteczności publicznej, takich jak basen, park czy Dom Zdrojowy. Według Andrzeja Podżorskiego w Wiśle obok pokazów kinowych i teatralnych miało wkrótce powstać gminne kino. Przewodnik zdobiły piękne fotografie wydrukowane na papierze kredowym jako niepaginowane wkładki, a orientację w terenie ułatwiał plan centrum Wisły wraz z dolinami. Na schematycznej mapie naniesiono lokalizację obiektów użyteczności publicznej oraz szeregu pensjonatów, których reklamy znalazły się na końcu książki i odwrocie planu.

Najciekawszym nowym rozdziałem w trzeciej edycji przewodnika pozostaje tekst pt. Przyroda i ludzie, w którym Andrzej Podżorski informuje czytelników o pobytach w Wiśle znanych osób i specyfice miejscowości oraz jej mieszkańców. Obok standardowej wiedzy na temat górali mówiących staropolskim językiem Reja i Kochanowskiego autor podaje w nim opinie o Wiśle z końca XIX wieku autorstwa artystki dramatycznej scen warszawskich Heleny Marcello i Bolesława Prusa z początku XX wieku, informacje na temat pobytów znanych pisarzy i uczonych czy działających na miejscu organizacji społecznych, takich jak Polskie Towarzystwo Pedagogiczne. Najwięcej miejsca poświęca Julianowi Ochorowiczowi, którego pracy naukowej (i w ogóle twórczości także innych osób) sprzyjały zdaniem autora spokój i wiślańska przyroda. Daje zatem wyraz swej dumie, że dzieła uczonego są w Wiśle nie tylko studiowane, ale także przekładane na język polski i wydawane (Ochorowicz 1937) ${ }^{4}$. Dalej informuje, że wiślańska natura sprzyja rozwojowi życia duchowego, co owocuje działalnością różnych grup religijnych „wypełniających czynnie słowa ewangelii” i poszukujących Boga, oraz przestrzega, aby tego zjawiska nie oceniać powierzchownie jako sekciarstwa. Podaje również wiadomości, zupełnie niestandardowe w przewodnikach, o istnieniu i działalności w Wiśle ośrodka ezoterycznego. Wymienia nazwiska redaktorów i tytuły ukazujaccych

4 Chodziło o przekład z francuskiego dzieła De la suggestion mentale, którego dokonała Janina Dembowska-Duninowa, a wydał w serii Biblioteka „Lotosu” tom 8 Jan Hadyna. 
się w Wiśle czasopism, takich jak „Wyzwolenie”, które sam redagował, „Hejnał” i „Lotos” oraz seria „Książnica Wiedzy Duchowej” (Podżorski 1938). To pierwsze ujęcie religioznawcze tematu wielowyznaniowości oraz bogactwa światopoglądowego Wisły lat międzywojennych, niespotykane w żadnym innym wydawnictwie turystycznym tego okresu.

Osobne zagadnienie stanowią informacje Andrzeja Podżorskiego o pobytach znanych osób, zwłaszcza literatów, w Wiśle. Autor już w pierwszym wydaniu podawał za prasą, że na wypoczynek do Wisły w 1892 roku przybyła aktorka Helena Marcello z Warszawy, dalej, że miejscowość zwiedzili Maria Konopnicka i Bolesław Prus, który miał tu rozpocząć pracę nad swoją Placówka. W drugim wydaniu podawał, że Wisłę odwiedzili także Eliza Orzeszkowa i Tadeusz Boy-Żeleński, a w trzecim dodawał jeszcze pobyt Henryka Sienkiewicza. To Wisła miała zdaniem Andrzeja Podżorskiego zainspirować Marię Konopnicką do napisania Roty. Wobec późniejszej krytyki części tych twierdzeń dokonanej przez prof. Edmunda Rosnera oraz polemiki prasowej, która wywiązała się pomiędzy uczonym i autorem przewodnika, należy pochylić się nad tym zagadnieniem.

Z całą stanowczością stwierdzić wypada, że Bolesław Prus nie napisał w Wiśle Placówki, gdyż ta wydana została przed jego przyjazdem do Juliana Ochorowicza. Wątpliwa też, choć niewykluczona, jest wiślańska inspiracja dla Roty Marii Konopnickiej. Drukowana po raz pierwszy 7 listopada 1908 roku w „Gwiazdce Cieszyńskiej” i będąca odpowiedzią na sytuację w zaborze pruskim, opatrzona została przez autorkę dedykacją Ludowi śląskiemu (Szafrański 2017). Zważywszy, że poetka w tym okresie spędzała letnie miesiące w Wiśle w willi „Sokół” sióstr Cecylii i Ksawery Leśniewskich, niczego nie da się potwierdzić ani wykluczyć ${ }^{5}$. Z kolei Henryk Sienkiewicz i Eliza Orzeszkowa zapewne nigdy nie zawitali we wsi u stóp Baraniej Góry, choć jako osoby zaangażowane w organizację jubileuszu Marii Konopnickiej o niej słyszeli. Nazwa „Wisła” i wzmianka o projekcie zakupu domu dla poetki od Juliana Ochorowicza pojawiły się w korespondencji Elizy Orzeszkowej do przyjaciółki. Również pobyt Tadeusza Boya-Żeleńskiego nie został potwierdzony w źródłach, choć jego rodzina z Krakowa (Iza, wdowa po bracie Boya) gościła w willi „Koliba” Jerzego Warchałowskiego w 1915 roku (Kirkor-Kiedroniowa 1986). Wydaje się więc, że chcąc dodać Wiśle splendoru, Andrzej Podżorski na podstawie poszlak wyciągał czasem zbyt daleko idące wnioski (Podżorski 1962). Ciekawe jednak, że nie wspomniał o pobytach innych znanych osób w Wiśle. Jeszcze w latach międzywojennych nie wiedział o pracach Marii Wysłouchowej na temat wsi ani o pobycie Władysława Stanisława Reymonta, choć ten przybył do Juliana Ochorowicza rok po Bolesławie Prusie i pisał tu Chłopów (Czyż 2021). Zapewne zajętemu własną edukacją w Cieszynie młodemu człowiekowi te fakty po prostu umknęły.

5 W Muzeum Beskidzkim w Wiśle w teczce pt. „Andrzej Podżorski 1886-1971 Wisła”, sygn. BMB 2250 zachował się odpis listu Zofii Lazar z 1965 roku do Andrzeja Podżorskiego poświadczający pobyty Marii Konopnickiej w Wiśle ok. 1905-1908 roku oraz jego korespondencja do Muzeum Marii Konopnickiej w Żarnowcu z 1969 roku. 
Należy zwrócić uwagę, że przewodnik Andrzeja Podżorskiego nie powstał w próżni. Autor znał wcześniejsze wydawnictwa turystyczne polskie i niemieckie, które wymienia w rozdziale $Z$ głosów prasy o wiślańskim uzdrowisku lub cytuje w tekście. Początkowo cierpiał na brak dostępu do archiwalnych wydawnictw, z czasem poszerzał swą wiedzę, a tym samym bibliografię. Trudno jednak wskazać, aby wzorował się na którymkolwiek wydawnictwie lub na istniejących przewodnikach. Niewątpliwie znał dawne, wspomniane prace Bogumiła Hoffa i książeczkę o rzece Wiśle Konstantego Krynickiego (Krynicki 1906: s. 17), przewodniki wydane za czasów austrowęgierskich: niemiecki Jozefa Matzury i polski ks. Antoniego Macoszka (Matzura 1891, Macoszek 1901), a także nowsze opracowania: Mieczysława Orłowicza po województwie śląskim oraz Kazimierza Sosnkowskiego po Beskidzie Zachodnim (Orłowicz 1924, Sosnowski 1926). Korzystał z opisów wsi zamieszczanych w prasie autorstwa Apoloniusza Tomkowicza, Franciszka Rawity-Gawrońskiego, którego poznał w Wiśle i Władysława Umińskiego (Tomkowicz 1837, Rawita-Gawroński 1920, Umiński 1934). Te wszystkie prace zapewne nie zadowalały go, gdyż opisy sporządzone przez osoby przybywające z zewnątrz zawierały błędy, a ich autorzy narzucali swoje poglądy i porównania (najczęściej z Zakopanem) lub traktowali Wisłę bardzo pobieżnie. Dlatego postanowił przygotować własne opracowanie, które stale udoskonalał. Mimo że autor czerpał z innych wydawnictw, jego praca pozostaje na wskroś oryginalna.

Po II wojnie światowej, kiedy Wisła stała się dużym ośrodkiem wczasowym, Andrzej Podżorski przygotował do druku jednoarkuszowy Informator dla przyjeżdzajacych do Wisty (w 1959 roku) oraz kolejne, czwarte wydanie swojego przewodnika. Niestety komunistyczny system z niedoborami papieru storpedował to przedsięwzięcie i autor nie mógł znaleźć wydawcy (Sosna 1961). Niemniej mając prawie 70 lat, zaangażował się w tworzenie wiślańskiego Koła PTTK, które powstało w 1955 roku. Był członkiem zarządu i przewodniczącym sekcji kulturalno-oświatowej, prowadził kronikę i organizował, a także sam wygłaszał prelekcje, m.in. relacje z wycieczek (Podżorska 1961). W 1958 roku zorganizował kurs dla przewodników, na którym wykładał, jego dziełem były też tablice informacyjne o roślinach chronionych ustawione przy dworcu kolejowym (Sosna 1961). Za wkład w rozwój turystyki otrzymał dyplom PTTK i do końca życia pełnił funkcję społecznego opiekuna zabytków PTTK (Podżorski 1970, Pustówka 1994).

Turystyka była nie jedyną, ale jedną z najwcześniejszych i najbardziej trwałych pasji Andrzeja Podżorskiego. Jego działania wynikały z troski o przyjeżdżających do Wisły gości i chęci zapoznania ich ze specyfiką miejscowości oraz regionu Śląska Cieszyńskiego. W latach 30. XX wieku w nowoczesnych przewodnikach przekazywał obok informacji standardowych także i nietypowe, wynikające z jego szerokich zainteresowań. Promował nie tylko swoją miejscowość, ale także zdrowy styl życia, nowe idee i światopoglądy oraz sporty letnie i zimowe zdobywające w okresie międzywojennym coraz większą popularność. Bronił natury, której wartość dla życia człowieka doceniał, przestrzegał przed 
urbanizacją i industrializacją beskidzkich miejscowości. Szczególną uwagę zwracał na kulturę, nie tylko ludową, materialną i duchową, ale i tę tworzoną przez nowych wiślańskich osadników oraz gości. Jeszcze nie mógł wskazać turyście konkretnych budynków związanych z kulturą, a przeznaczonych do zwiedzania, ale z perspektywy czasu można Andrzeja Podżorskiego nazwać nie tylko założycielem Muzeum Beskidzkiego, ale również pionierem turystyki kulturowej w Beskidach. Kreował na wskroś nowoczesny i oryginalny wizerunek Wisły oraz regionu Śląska Cieszyńskiego.

\section{Literatura}

Czyż R., 2014, Zanim przybyt Hoff... Wyprawy naukowo-badawcze i podróże do źródet Wisty, [w:] Czyż R. (red.), Bogumit Hoff (1829-1894) - „odkrywca” Wisty, Wydawnictwo Luteranin, Wisła, s. 7-26.

Czyż R., 2021, Literatura, [w:] Czyż R., Miśka H., Kawulok M., Wisła. Literatura - muzyka - sztuki plastyczne, Monografia Wisły, t. 5, Galeria „Na Gojach” / Urząd Miasta Wisła, Wisła, s. 13-45.

Galicz J., 1931, Przewodnik po Beskidzie Ślaskim od Baraniej po Ostrawicę i Śląsu Cieszyńskim ze szczególnym uwzględnieniem miasta Cieszyna, Oddział Cieszyński PTT „Beskid Śląski”, Cieszyn.

Kirkor-Kiedroniowa Z., 1986, Wspomnienia. Cz. I. Dziecięce i młode lata, Wydawnictwo Literackie, Kraków.

Krynicki K., 1906, O Wiśle, jej dopływach i miastach nad nią leżacych, wyd. 5, Warszawa.

Macoszek A., 1901, Przewodnik po Ślasku Cieszyńskim wraz z opisem topograficzno-etnograficznym i szkicem dziejów księstwa cieszyńskiego, Towarzystwo Wydawnicze, Lwów.

Matzura J., 1891, Illustrirter Führer durch die Beskiden und die angrenzenden Landschaften. (Von der Betschwa bis zum Dunajetz; von Breslau zur Tatra; von Prerau bis Krakau-Wieliczka; die Städtebahn von Kojetin bis Kalwarya; Führer im Gebirge: zum Radhost, zur Lissa, zu den Weichselquellen, zur Babiagura; das obere Waagthal, Sulov; die Arva; Curorte), Verlag von Eduard Feitzinger, Teschen.

Ochorowicz J., 1937, O sugestji myślowej, Biblioteka „Lotosu”, nr 8, Red. „Lotosu”, Kraków.

Orłowicz M., 1924, Ilustrowany przewodnik po województwie śląskim, Książnica Polska Towarzystwa Nauczycieli Szkół Wyższych, Warszawa - Lwów.

Podżorska M., 1961, Wiślańskie Koło PTTK, Na Szlakach. Biuletyn Koła PTTK przy Fabryce Maszyn Elektrycznych CELMA w Cieszynie, nr 4(13), s. 77-79.

Podżorski A., 1930, Ilustrowany przewodnik po Wiśle z mapka Wisty, Ustroń.

Podżorski A., 1933-1934, Nowy przewodnik po Wiśle z mapa, Cieszyn.

Podżorski A., 1938, Przewodnik po Wiśle z mapa turystyczną Ślaska Cieszyńskiego i planem centrum Wisty i okolicy, Cieszyn. 
Podżorski A., 1961, Początki turystyki w Wiśle, Na Szlakach. Biuletyn Koła PTTK przy Fabryce Maszyn Elektrycznych CELMA w Cieszynie, nr 4 (13), s. 84-87.

P.[odżorski] A., 1962, Czy „Rota” Konopnickiej i „Placówka” B. Prusa powstały w Wiśle?, Głos Ziemi Cieszyńskiej, nr 26, s. 4.

Podżorski A., 1970, Życiorysy Andrzeja Podżorskiego (mps), Biblioteka Muzeum Beskidzkiego w Wiśle, sygn. MWB 1534.

Podżorski A., 1994, Wspomnienie o moim ojcu, [w:] Kiereś M. (red.), Dawne rzemiosto w Beskidzie Śląskim w badaniach Andrzeja Podżorskiego, Muzeum Beskidzkie i Wojewódzki Ośrodek Kultury, Wisła, s. 56-57.

Podżorski J., 1994, Andrzej Podżorski - znany i nieznany, [w:] Kiereś M. (red.), Dawne rzemiosto $w$ Beskidzie Śląskim w badaniach Andrzeja Podżorskiego, Muzeum Beskidzkie i Wojewódzki Ośrodek Kultury, Wisła, s. 52-55.

Pustówka H., 1994, Życie i działalność Andrzeja Podżorskiego, [w:] Kiereś M. (red.), Dawne rzemiosło $w$ Beskidzie Ślaskim $w$ badaniach Andrzeja Podżorskiego, Muzeum Beskidzkie i Wojewódzki Ośrodek Kultury, Wisła, s. 7-14.

Rawita-Gawroński F., 1920, Od źródet Wisty do Ustronia, Ziemia, nr 2, s. 44-53; nr 3, s. $84-88$.

Sikora S., 1985, Tradycje turystyki polskiej na Ślasku Cieszyńskim, [w:] Chmiel K., Sosna W., Szupina A. (red.), Od PTT do PTTK na Ziemi Cieszyńskiej, Oddział PTTK „Beskid Śląski”, Cieszyn, s. 9-17.

Sosna W., 1961, Sylwetki 50-lecia. Andrzej Podżorski, Na Szlakach. Biuletyn Koła PTTK przy Fabryce Maszyn Elektrycznych CELMA w Cieszynie, nr 4 (13), s. 80-84.

Sosnowski K., 1926, Przewodnik po Beskidach Zachodnich: od Krynicy po granice Moraw łacznie z Pieninami i terenami narciarskimi, Księgarnia Geograficzna „Orbis”, Kraków.

Spyra J., 2007, Wisła. Dzieje beskidzkiej wsi do 1918 roku, Monografia Wisły, t. 2, Galeria „Na Gojach” / Urząd Miasta Wisła, Wisła.

Szafrański M., 2017, Wojciech Święs: Rota po raz pierwszy ukazała się drukiem w Gwiazdce Cieszyńskiej, https://dzieje.pl/kultura-i-sztuka/wojciech-swies-rota-poraz-pierwszy-ukazala-sie-drukiem-w-gwiazdce-cieszynskiej [dostęp: 22.09.2021].

Szczypka D., Pylypenko-Czepczor A., 2017, Wista. Dzieje miejscowości w latach 1918-1945, Monografia Wisły, t. 4, Galeria „Na Gojach” / Urząd Miasta Wisła, Wisła, s. 91-99.

Tomkowicz A., 1837, Źródła Wisły, Sławianin, t. 1, Lwów, s. 155-159.

Umiński W., 1934, Moje wspomnienia z pobytu na Śląsku Cieszyńskim, Zaranie Śląskie, nr 2, s. 95-97.

Wantuła A., 1937, Od starej ku wspótczesnej Wiśle, jej teraźniejszość, Zaranie Śląskie, nr 3, s. 155-162.

Wysłouchowa M., 1900, Ku źródłom Wisty, Zorza, nr 5, s. 65-67; nr 6, s. 90-91. 